\title{
SEMIOLINGUISTICS OF PROTECTIVE COMMUNICATION
}

\author{
Tatyana N. Astafurova \\ Volgograd State University, Volgograd, Russia; \\ Volgograd State Technical University, Volgograd, Russia \\ Andrey V. Olyanich \\ Adyghe State University, Maykop, Russia
}

\begin{abstract}
The current paper investigates the notion of protective communication represented by systems of signs, texts, rituals which the authors regard as means of neutralizing cognitive constructs, generated by phobias of varying degrees of irrationality. Classification of phobias on psycho- and sociolinguistic grounds allows developing their typology from the point of view of the cause of their origin: supernatural entities (superstition), individual fearful images (prejudice), social suspicion (bias). As the study showed, sacred horror caused by destructive forces of nature, climatic phenomena not subjected to man, and astronomical events gave rise to supernatural, esoteric phobias reflected in superstitions. Biological phobias appeared in response to real dangers, associated with daily human activities, personal imaginary troubles and fears, which generated a system of prejudice invented by man himself. Social interaction of people, with its negative stereotyping and categorization of social space, entailed a wide range of phobias (racial, religious, age, gender, etc,) which turned into social biases. On his way of development, a man tried hard to find protection against phobias of different nature, creating an extensive system of protective means incorporated in religious, magical and intolerant types of discourse, consequently neutralizing superstitions, prejudices and biases in specific genres, verbal and non-verbal signs, texts and rituals of the above mentioned types of discourse.

Key words: protective communication, superstition, prejudice, bias, religious discourse, magical discourse, intolerant discourse.

Citation. Astafurova T.N., Olyanich A.V. Semiolinguistics of Protective Communication. Vestnik Volgogradskogo gosudarstvennogo universiteta. Seriya 2. Yazykoznanie [Science Journal of Volgograd State University. Linguistics], 2019, vol. 18, no. 3, pp. 172-181. DOI: https://doi.org/10.15688/jvolsu2.2019.3.14
\end{abstract}

УДК 81’22:005.57

Дата поступления статьи: 24.01.2019

ББК 81.002 Дата принятия статьи: 10.06.2019

\section{ЛИНГВОСЕМИОТИКА ПРОТЕКТИВНОЙ КОММУНИКАЦИИ}

\section{Татьяна Николаевна Астафурова}

Волгоградский государственный университет, г. Волгоград, Россия; Волгоградский государственный технический университет,

г. Волгоград, Россия

\section{Андрей Владимирович Олянич}

Адыгейский государственный университет, г. Майкоп, Россия

Аннотация. В статье рассматривается феномен протективной коммуникации, представленной системами знаков, текстов, ритуалов, которые авторы репрезентируют как средства нейтрализации когнитивных конструкций, порождаемых фобиями различной степени иррациональности. Классификация фобий по психо- и социолингвистическим критериям позволила разработать их типологию с точки зрения причи- 
ны возникновения: эзотерические, личностные, социальные. Как показало исследование, священный ужас перед разрушительными природными, климатическими, астрономическими явлениями, не зависящими от человека, привел к возникновению фобий сверхъестественного, эзотерического характера; которые породили суеверия. Биологические фобии возникли в ответ на реальные опасности, связанные с повседневной деятельностью и личными воображаемыми страхами людей. Эти фобии составили основу системы предрассудков. Институциональное взаимодействие людей обусловило негативную категоризацию / стереотипизацию социального пространства и появление фобий, в результате которых образовались предубеждения расового, религиозного, полового, возрастного и пр. характера. На протяжении своего развития человек пытался найти защиту от разного рода фобий, создавая разветвленную систему протективных средств в рамках религиозного, магического, интолерантного дискурсов, нейтрализующих суеверия, предрассудки и предубеждения в конкретных жанрах, вербальных и невербальных знаках, текстах и ритуалах названных дискурсов.

Ключевые слова: протективная коммуникация, суеверие, предрассудок, предубеждение, религиозный дискурс, магический дискурс, интолерантный дискурс.

Цитирование. Астафурова Т. Н., Олянич А. В. Лингвосемиотика протективной коммуникации // Вестник Волгоградского государственного университета. Серия 2, Языкознание. - 2019. - Т. 18, № 3. - С. 172-181. (На англ. яз.). - DOI: https://doi.org/10.15688/jvolsu2.2019.3.14

\section{The phenomenon of protective communication}

Semiolinguistic models of protective communication include systems of signs, texts, rituals that neutralize cognitive constructs (superstitions, prejudices, preconceptions) generated by phobias of varying irrationality degrees and fixed respectively to religious, magic and intolerant types of discourses.

Semiotics (Greek semeion - a sign) is a field of knowledge that deals with the comparative study of sign systems from the simplest signaling systems to natural languages and formalized languages of science [Benveniste, 1971; Morris, 1938]. The main functions of the sign system are: 1) transmitting a message or expressing meaning; 2) ensuring addressee perceives a transmitted message motivation with a respond of being emotionally impacted.

Implementing any of these functions implies a certain internal organization of sign systems and laws of their combinability.

Cognitive mastering of the world by man is inseparably linked with semiosis, understood as the process of sign presentation of information in all spheres of natural and social life, where information exchanges occur [Mechkovskaya, 1998]. The most ancient example of such a process is the semiosis of prejudice, which is a mode for Homo sapiens to combat forces of nature and his fear of them, ensuring survival of man as a species. Irrational fear, enshrined in the ethno-specific system of omen signs, helped to obtain information about sources of danger of esoteric, natural and tribal character and develop a special type of communication that would neutralize these fears.

Nature "warns" a man about danger with signs of different properties and purposes, and a man, decoding these signs, masters his communicative behavior in accordance with the received semiotic information. Danger signs form an algorithm to counteract prejudice and become part of ethnos irrational picture of the world. Primitive irrational fears of hostile, inaccessible to perceiving forces of nature that threaten the security of human existence, greatly influenced ancient conceptualization of the world. Having learned to distinguish degrees of danger of certain phenomena through cognitive acquisition of environment in past times, modern man still retains these subconscious archaic structures of cognition, they are based on irrational phobias and gave rise to a complex system of prejudice [Astafurova, Olyanich, 2018].

Phobias accompany man throughout his life, penetrate into all spheres of activity, develop with him, change forms of their manifestation, expand the list of their causes. Initially, there existed esoteric and biological phobias (primitive, as response to real dangers of life), which gave rise to different types of prejudice. With the development of social relations, social phobias appear, giving rise to prejudice associated with threats of social character: poverty, violence, social exclusion, etc.

Classification of phobias on psycho- and sociolinguistic grounds [Luria, 1998; Shcherbatykh, 
2007] allows developing a typology of the phenomenon under study from the point of view of the cause of its occurrence. Causes of phobias can be diversified: 1) supernatural, esoteric, independent of man, 2) determined by personal factors, i.e. come up with a man, 3) established by social factors associated with institutional interaction of members within ethnic group. The types of phobias are presented in Figure 1.

Esoteric phobias, as compared to social phobias, are more ancient and genetically determined. The cause of this type of phobias is connected with external factors in the form of natural phenomena, natural disasters, i.e. the event that a person can neither change nor predict, or avoid. In the language, such phobias are verbalized with the help of mono-semantic composite lexemes of Greek-Latin origin: staoprophobia (fear of crosses and crucifixes), agiophobia (fear of sacred objects), teleophobia (fear of religious ceremonies). These are also phobias associated with the manifestation of natural phenomena, such as brontophobia (fear of thunder and lightning), eosophobia (fear of the day), selenophobia (fear of the moon), nektofobiya (fear of the night), photophobia (fear of light) and photo-uglofobiya (fear of bright light), chionophobia (fear of snow), ombrofobiya (fear of rain), anthlofobiya (fear of floods), etc.

The nature of personal phobias is different: it is not genetically determined, but has an acquired character, largely dependent on the psyche of the individual and the fears imagined. According to Y. Shcherbatykh, an animal can fear only specific dangers, but a person is afraid of imaginary troubles due to his imagination [Shcherbatykh, 2007]. Personal phobias are commonly understood as fears caused by human internal mental processes resulting from the work of the human imagination and verbalized by mono-semantic units: virginitiphobia (fear of rape), isolophobia (fear of loneliness), atazogorophobia (remain unnoticed by society) In the framework of personal phobias, in our opinion, we can consider tanatophobia (fear of death), taffephobia (fear of being buried alive), hemophobia (fear of blood), etc. The basis of these phobias are, as a rule, real reasons that are caused by the active work of human thought, originating and existing in human imagination. Really reasonable phobias include such as latrophobia (fear of visiting the doctor), siderodromophobia (fear of traveling by train), monophobia (fear of being alone), clinophobia (fear of going to bed), ablutophobia (fear of swimming), aerophobia (fear of flying), glossophobia (fear of public speaking), godophobia (fear of traveling), cyberphobia (fear of working at a computer), etc.

Social phobias arise as a result of stereotyping and negative categorization of institutional space (an alien relation to objects of prejudice on racial, religious, class, group, sex, age, sexual and other grounds). Among social phobias, the most frequent are xenophobia (fear of strangers), peniophobia (fear of poverty), plutophobia (fear of wealth), hypheniophobia (fear of responsibility), elefterofobiya (fear of freedom), enissofobia (fear of social criticism), lithicophobia (fear of lawsuits), rhabdophobia (fear of social punishment), cathagelophobia (fear of social ridicule), etc.

Phobias semiosis is a complex dynamic phenomenon, which is based on:

- supernatural entities underlying sacred horror (awe) before destructive natural, climatic,

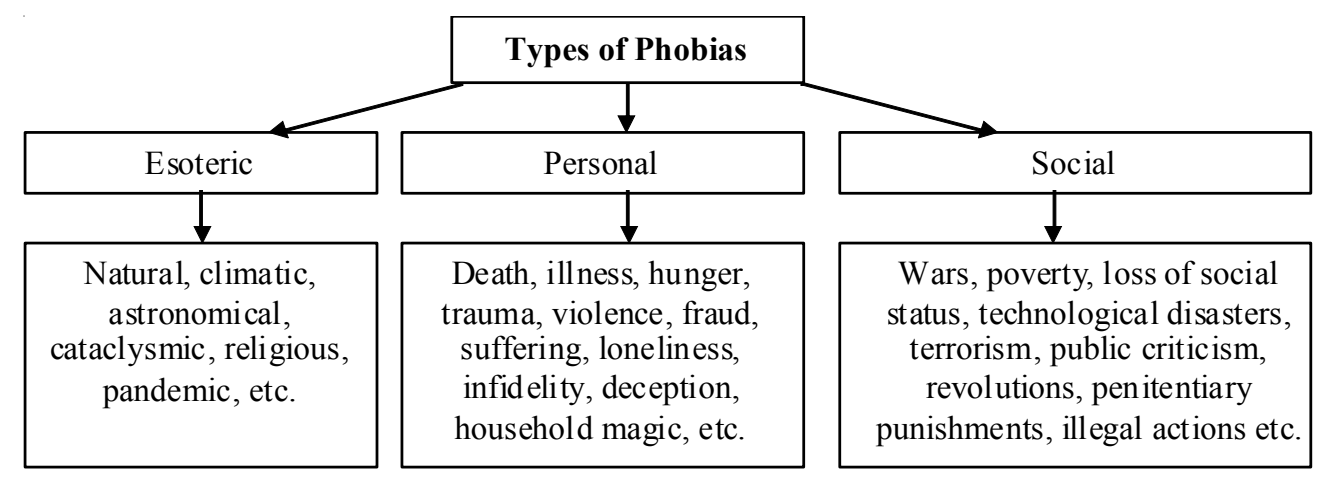

Fig. 1. The types of phobias 
astronomical phenomena, pandemic and endemic cataclysms as manifestations of the higher forces of Evil, which were protected in ancient times by worshiping sacred symbols, performing sacral rituals and following religious precepts as manifestations of the higher powers of God;

- mental constructs, generating in individual consciousness fearful images of death, disease, hunger, trauma, violence, suffering, loneliness, deceit, etc., to relieve the fear of which people turned to means of "everyday magic" (charms, spells, amulets, talismans, etc.);

- social suspicion (mistrust) of racial, ethnic, class, group, gender, age, sexual and other alienation, preventing adequate perception of the object of alimentation, which is expressed in fear of power, poverty, war, revolution, terrorism, man-made disasters, unlawful actions of antisocial elements, social reprimand, penitentiary punishments, etc.

Different types of phobias give rise to corresponding prejudices, which are characterized by universal, national and ethno-specific parameters. Superstitions are generated by esoteric phenomena which are inaccessible to rational analysis of a person and as a result are the basis for the emergence of various kinds of superstitions. The endowment of an object, phenomenon, process with an unusual quality, sacred content leads to their sacralization, i.e. to their realization through symbol, word, ceremonial / ritual texts, representing the sacred code of esoteric information. Thus, sacredness is connected with the semiosis of superstition as a process of meaningfulness of the irrational world phenomena which are not cognitively mastered by ordinary consciousness.

Prejudices arise as a result of the work of human imagination based on personal experiences and unmotivated reactions to fears caused by the events of the outside world. Prejudices constantly accompany a person throughout his / her life, have a pronounced ethno-specific marking and retain their stability even in case when fears themselves are groundless. Biases result from negative interpersonal, intergroup, interclass and other interactions, as well as communicative practices that generate psychological attitudes that distort the object, negatively stereotyping it, thus preventing adequate perception of information due to its uncritical use. Socially-marked opposition "native vs. alien" lies at the bottom of prejudiced personal interaction, generating racial, ethnic, age, gender, status, political and other types of prejudices.

The distinction between superstitions, prejudices and biases is associated not only with different types of phobias, but also with different areas of neutralizing them, which correlate with religion (superstition), everyday magic (prejudice) and social intolerance (bias). Therefore, religious, magical and intolerant types of discourse form a semiolinguistic space of protective communication, aimed at protecting from "after life" punishment for unjust acts, everyday and psychosomatic dangers, social aggression and discrimination.

\section{Protection against superstitions in religious discourse}

Superstitions as phenomena of esoteric origin are based on symbolic essences, and ways of neutralizing phobias that generate them are revealed in religious and mythological knowledge, divine revelations and theological chronotopology. They appear as signs and myths in the multi-genre sacred texts of religious discourse: the Old and New Testaments, revelations and lives of saints, prayers, psalms. Religious discourse is organized around a key concept - Faith - as a trust union of man with God and is based on compliance with the moral law specified in the commandments; it functions and manifests itself in typical chronotopes, rituals, genres and precedent texts. The main pragmatic functions of religious discourse are protection from punishment for mortal sins, reward for believers following the Ten Commandments of God and resisting temptation to commit the seven mortal sins (pride, anger, envy, murder, lust, gluttony, covetousness).

Prayers and psalms, being precedent sacral texts, serve as verbal means of moral purification, neutralizing superstitious fear (awe $=$ holy fear) of death, horrors of the Last Judgment (Doomsday Trial) and the torments of burning in hell, as punishment in the future afterlife. The basic religious maxims that regulate virtuous behavior are prescriptive: prohibition of idolatry; prohibition of adultery; prohibition of stealing; prohibition of idolatry; prohibition of false testimony; prohibition of coveting a neighbor's property; prohibition against coveting a neighbor's wife.

The removal of superstitious fear is greatly facilitated by religious semiotics (the Cross $=$ symbol of Christianity, the Holy Trinity = symbol 
of Christianity, the Star of Bethlehem = symbol of Messiah as the savior and liberator of humankind) and the rituals (Christmas = festival held on December 25 to celebrate the birth of Jesus Christ; Good Friday = Friday immediately preceding Easter, celebrated by Christians as the anniversary of Christ's crucifixion; Easter = Christian feast commemorating the Resurrection of Jesus; the Eucharist, etc).

Various sacred texts of religious discourse reflect the theosophical system of religious ideas (concepts) about God and his commandments, the other world and the Lord's judgment, paradise as a reward for righteous life and hell as punishment for unjust acts, ways of salvation due to adherence to religious and ethical norms and rituals.

Ritual semiolinguistics is deliberately archaic: a significant number of archaic verbal signs and their combinations mark cognitive processes and unshakable theosophical tenets that have not changed for thousands of years. This is manifested in the use of obsolete lexical units: thee (object form of "you"), thou (you), thy (your), beseech (ask eagerly and anxiously); affianced (engaged); wrought (worked, done), smite (punish), hearken (listen to), etc.; grammatical forms of standeth (stands), art (are), shalt (shall); behold (look at ...); thou smitest (you punish); be it done unto ...; blessed art thou.

In religious discourse we distinguish primary and secondary speech genres: psalms, parables and prayers as primary ones refer to precedent religious texts, primary sources; sermons and confessions as interpretation of primary genres refer to secondary ones. The main subject concentrates around the issues of man's belief in a supernatural element, fear of punishment for sinful acts and hopes for forgiveness, bringing happiness and welfare in the afterlife.

Anglican religious communication involves virtual (the God, Jesus Christ, the Virgin Mary, Saints, Angels, etc.) and real participants as intermediaries of intercourse with God (priests, bishops, abbots, monks, deans, deacons, vicars) and flocks (believers, churchgoers, congregation).

Values and anti-values of Anglican religious discourse are represented by the following concept spheres:

- The Good and its categories - Virtue, Chastity, Temperance, Charity, Diligence, Forgiveness, Kindness, Humility;
- The Evil and its categories - vice, pride, lust, gluttony, greed, sloth, wrath, envy.

Religious discourse is characterized by appellative, ritual, prohibitive, inspirational and protective functions. The latter is the leading one and associated with sacred fear of punishment for the sins committed in earthly life. Protective function of the sacred text of Psalm 91 is realized through nominations of salvation promise, protection and defense (For he shall give his angels charge over thee: to keep thee in all thy ways; They shall bear thee in their hands: that thou hurt not thy foot against a stone) [bible.com $>$ bible/1/PSA.91], getting rid of the fear of physical and moral suffering under the condition of love for God, faith in him and the fulfillment of his commandments.

Parables are the basic element of pastoral conversations, which describe examples of God's protection of true Christians and the miracles performed by him (Christ's resurrection of Lazarus; healing a leper, a lame man, a blind man; God satisfying the famine of sufferers with bread, etc.). Most parables are based on allegory, in which text literal meaning hides its original one, which is easily predicted, understood and deduced from the content.

Thus, semiolinguistic model of neutralizing esoteric phobias which generate superstitions (see Fig. 2) is based on universal, sustainable, rational presuppositions of sacred awe. Their neutralization is carried out in religious discourse through the observance of religious precepts, following moral and ethical maxims / dogmas and Christian rituals, fulfillment of which grants reward in the afterlife (Paradise), and their violation threatens punishment (Hell).

\section{Protection against prejudice in magic discourse}

Prejudices that go back to the naive picture of the world are categorized in magical texts, which allow them to psychologically counteract negative influence of the environment. Such texts and related ritual actions may be referred to everyday magic discourse and function in relevant genres: spells, charms, love spell, removal of spoiling and damage, etc. Ontological, primary consciousness believes that the word has magical power if pronounced in a certain way and at a 


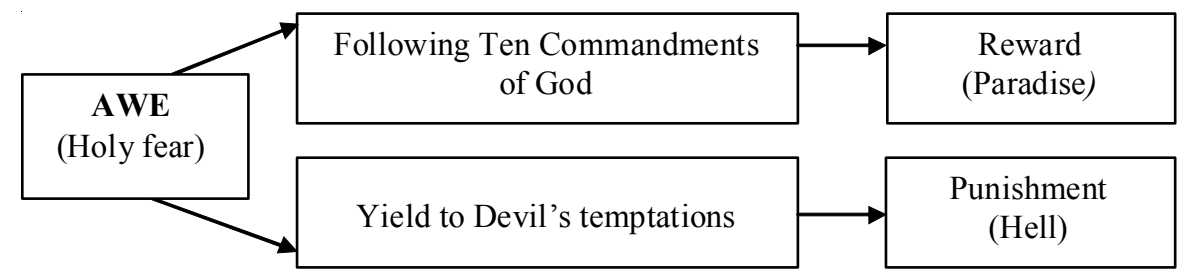

Fig. 2. Semiolinguistic model of neutralizing esoteric phobias which generate superstitions

certain moment, i.e. it is capable of impacting reality, causing changes in it and, to a large extent, influencing behavior of a modern man. At the household level, this is manifested in having a dread of the evil word, addressing mysticism, using spells and charms.

Magical thinking is hidden deep in the subconscious and floats to the surface in situations which require psychological protection from a wide range of personal phobias. Following the logic of a charm text, it is possible to change the state of things, verbally denoting not only all possible "objects of application" of magic power, but bringing together lexemes that have a formallysemantic similarity as well.

Unlike religious discourse, based on sacredness as the basis for neutralizing esoteric phobias, magical discourse is based on the mystical content of texts. Its participants are clients (persons in need of protection and healing) and agents of magic (persons using techniques of magical protection and healing). Axiological system of magical discourse is formed by the intentional dyad "virtue - evil", which includes positive values (philanthropy, hard work, honesty, chastity, generosity, health, etc.) opposed to negative antivalues (hate, deception, slander, disease, damage, greed, adultery). Axiological significance of the distinguished constants makes it possible to define them as a means of parametrizing universal folk experience which is ethnospecifically reflected in national paremiology and aphoristics.

Magic discourse realizes protective functions associated with drive-away and purifying magic and is aimed at neutralizing household phobias (fear of illness, failure, mystical negative influence of the evil eye, etc.) with the help of:

- magical semiotics (charms, amulets, talismans, tools, etc.);

- magical verbalica (texts of spells and charms, signs, etc., describing mechanism of human influence on the world around us in order to protect against its negative impact);

- mystical artifacts (dummies, wax figure, bells, candle, magic recipe, brew, broth, needle, thread, jar, moly, wand, wand, magic ring, magic mirror), to which suggestive power is attributed within the framework of protective magical ritual.

Magical herbs that protect against evil spirits and witchcraft are endowed with a special suggestive force: anise, its leaves protect from the elements and human vices; bay (laurel) has power to heal, purify, break hexes, remove family curses, to remove the evil eye; juniper is used to guard against black magic, supernatural entities, enemies, disease and accidents; elder (elderberry) is used to destroy evil forces, bringing well-being, luck, love, physical health, fulfillment of desires; acacia is used to liberate from ill influence of illwishers, to increase psychic powers, etc.

A different combination of prognostics, suggestion and action semiotics makes it possible to distinguish in magic discourse genres that provide a protective function:

- verbal-prognostic, aimed at prediction, warning of danger and anticipation / reaction to protective predictions $($ omen $=$ prognostic sign);

- verbal suggestive, aimed at executing magic (chant $=$ a suggestive monotonous rhythmic and rhymed protection; verse or formula charms);

- verbal action, aimed at executing household magic rituals which support magic texts in the form of spells (charm $=$ a magic action or word).

From the semiolinguistic point of view, the most interesting is the verbal- actional genre of magic discourse, pragmatic setting of which is mystical action - the ritual accompanying protective spell text [Astafurova, Olyanich, 2015]. A survey of Internet respondents on websites demonstrating methods of protection using everyday magic, revealed most frequent types of spells used as protections. They include: purification spell to break a curse, fire protection spell, anti-slander spell, spell against a trouble- 
maker, protection spell for reputation, spell to make an enemy move away, spell to stop someone from stealing, etc.

Magic text has a clearly pronounced protective potential, it is symbolically saturated and implements basic strategies of caution, correction and protection. Caution is expressed in prognostic attitudes (verbal-prognostic genre) aimed at warning about possible dangers reflected in the ethnospecific system of warning signs. Correction is aimed at healing ailments and normalizing deviant psychosomatic state due to clearly algorithmized, semiotically rich rituals and plots (verbal-suggestive genre). Protection is connected with defending against hostile external influence through spells and symbolically rich rituals (verbal-actional genre).

Poetic and rhymed form of spells, supported by magical signs and artifacts, aim at neutralizing fears. Prognostic signs of good / bad luck may be of different nature:

- anthropomorphic (It's very lucky to meet a chimney sweep by chance. Make a wish when meeting one, and the wish will come true);

- somatic (If your nose itches you will soon be kissed by a fool);

- actional (If you make a wish throwing a coin into a fountain, the wish will come true; if you tell someone your wish, it won't come true);

- zoomorphic (It is a bad luck to see an owl in the sunlight; to kill a raven is to harm the spirit of King Arthur who visits the world in the form of a raven);

- phloromorphic (Ivy growing near a house protects the inhabitants from witchcraft and evil);

- gluttonic (Put salt on the doorstep of a new house and no evil will enter);

- naturmorphic (A rainbow in the Eastern sky, the morrow will be fine and dry);

- artifactal (If someone sweeping the floor sweeps over your feet, you'll never get married);

- coloromorphic (A red ribbon should be placed on a child who has been sick to keep the illness from returning);
- numerological (Counting crows - One is bad, Two is luck, Three is health, Four is wealth, Five is sickness, Six is death; sneeze - One for sorrow, Two for joy, Three for a letter, Four for a boy);

- ritual (A wedding day with certain days of the week, and certain months of the year being good or ill signs for a wedding: "Married when the year is new, he will be loving, kind and true; When February birds do mate, You wed nor dread your fate; When December snows fall fast, marry and true love will last").

Thus, semiolinguistic model of neutralizing phobias that generate household prejudices (Fig. 3) is aimed at perceiving a system of luck / failure signs, predicting safety / danger of life situations. This semiolinguistic system of prognostic signs, fixed in ethno-cognition, is based on the nationally specific behavioral presuppositions of irrational nature. The prognostic signs of failure are neutralized in everyday magical discourse through mystical texts of spells, charms, removal of spoiling and damage; they are aimed at ensuring individual security, self-confidence and self-defense.

\section{Protection against bias in intolerant discourse}

Prejudice or bias as a prototypical concept of racial, ethnic, class, age, gender, and professional inequality verbalizes in intolerant (discriminatory) discourse or discourse of hatred, intolerance [Dijk, 1985] with its agonic ideology. It is the fear of an alien / stranger that generates "outrageous" texts containing ideologies of hatred and rejection of ethnic and social groups within a certain ethno-culture.

The way representatives of one ethnic group talk about "other" ethnic groups depends on various factors. "Others" can be represented both in neutral or positive light, but at the same time, "others" can be represented as an alien / dangerous social group, ridiculing it miserably, hanging a derogatory label on it or giving it a contemptuous nickname. In this case, linguistic

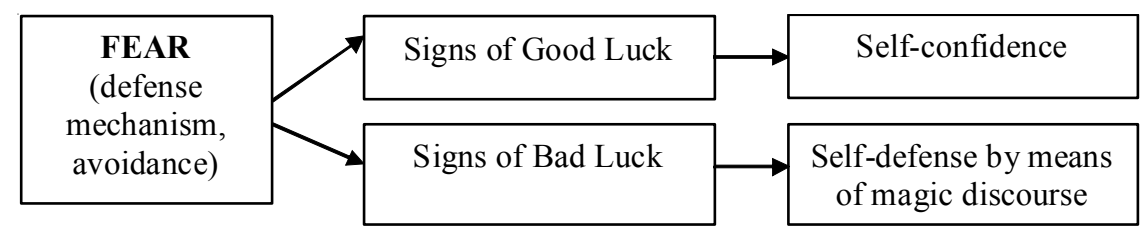

Fig. 3. Semiolinguistic model of neutralizing personal phobias which generate household prejudices 
markers of intolerant discourse appear, since alien out-group description is perceived as a hidden danger [Wodak, 1996].

Bias system is inspired by representatives of in-group, and is based on different interests and meanings. Bias against representatives of another race, ethnic / minority group, gender, profession, age, carriers of socially dangerous diseases, etc. is based on different traditions and used for different political purposes [Allport, 1954]. Semiosis of bias is made up of a system of alienator signs, acting as negative labels and nicknames that mark stereotypical notions of dominant in-group about marginal out-group. Alienator signs are not homogeneous in their composition and can be classified according to gradual scale of language aggression: anti-locution (denigrative) signs, avoidance (separative) signs and discriminatory signs, which are implemented in mass media communication.

Neutralizing language aggression and, accordingly, social bias, is carried out in carnival (laughter) genres of intolerant discourse, namely, in speech genres of harmless joke (humor), derogatory / abusive anecdote (irony) and pejorative conversation (sarcasm).

Denigrative signs are based on negative English stereotypes and images which form strong bias system using parameters of:

- Gender (broad $=$ mildly offensive term referring to women, which is not acceptable in polite society);

-Age (pimply $=[$ slightly offensive $]$ applied to older people);

- Exterior $(t u b b y=[$ mildly offensive $]$ an underweight and short person, fat in the stomach; skinny $=$ [slightly derogative] thin, underweight).

Separative signs are associated with situations of social class alienation, in which implicit fear of in-group to lose its social superiority manifests itself. These include signs of class, group and profession isolation:

- Class (white trash $=$ a derogatory term directed at whites, esp. poor whites);

- Group (empty nester $=$ [derogative] applied to either member of a couple whose children have grown up and left home);

- Professional (dummy $=$ [offensive] professionally unskilled).

Discriminatory signs are characterized by agonality and aimed at depriving institutional rights of out-group representatives on the basis of false or fabricated stereotypes. The signs of discrimination can be of different character:

- Racial-ethnic (chink $=$ [highly derogative $]$ (U.S.) used to refer to people of perceived Chinese descent);

- Religious (Muhammadanism [strongly offensive] = the Muslim religion, Islam);

- Physiological (wheelchair $=$ [very offensive] a person who has physical disability).

Linguistic form of bias representation varies and depends on readership, content and context, but all discriminatory speech statements usually appeal to action, physical violence or destruction of relevant social minorities. Effective social communication based on Grice's maxims and J. Leech's cooperative principle implies elimination of social bias due to institutional prescriptive norms, certain semantic and formal requirements for mass media communication: objectivity, avoiding one's personal assessment, respecting standards of integrity and neutrality, representing opinions of others, etc., which distinguish tolerant discourse [Ivanova, 2002] with politically correct ideologems.

However, a number of researchers [Bakhtin, 1997; Condor, 2006; Dijk, 1985; Wetherell, 1987; Wodak, 1996] argue that social phobias can be neutralized primarily in intolerant (racist) discourse with varying degrees of agonality. According to them, the stronger social dangers provoke phobias, the more aggressive form of bias representation is. Signs of social alienation are ranked according to degree of agonality (denigrative, separative and discriminative) and neutralized respectively in "carnival" [Bakhtin, 1997] genres of intolerant discourse: humor (low degree of intolerance), irony (medium degree of intolerance) and sarcasm (high degree of intolerance).

Thus, semiolinguistic model of neutralizing phobias that generate social bias (see Fig. 4) is based on ethno-social and / or individual presuppositions of rational nature. Their variability is determined by danger / security indices attributed by representatives of in-group to members of out-group in the framework of intolerant discourse. Alienation of out-group representatives is neutralized by means of intolerant discourse of low, medium and high degree of communicative aggression. 


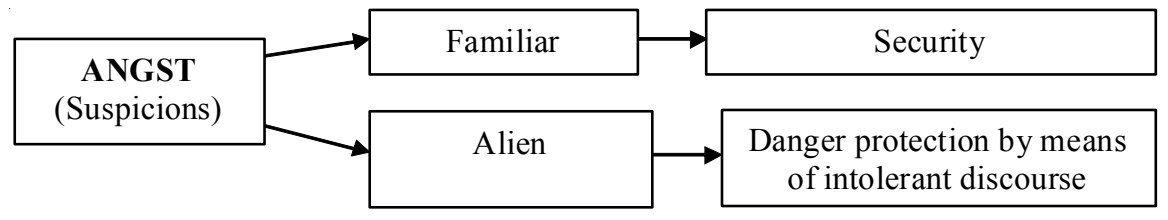

Fig. 4. Semiolinguistic model of neutralizing social phobias which generate bias

\section{Conclusion}

Consequently, superstitions, prejudice and bias, as complex lingua-cognitive constructs are generated by phobias, which are being neutralized in semiolinguistic space of protective communication. Protective communication includes religious, magical and intolerant types of discourses with their inherent verbal and nonverbal means of protecting man from threats and dangers of irrational (esoteric and personal phobias) and rational (social phobias) nature.

Verbal means of protective communication include texts of sustainable type, allowing attributing them to specific speech genres. Speech genres of protective communication are distinguished by the following parameters: communicative purpose, author, addressee, event content, language representation [Shmelyova, 1995]. In accordance with the distinguished content parameters, pragmatic function of protective communication genres is to protect the subject by means of religious, magical and intolerant types of discourse, within which he / she uses semiolinguistic security tools. Based on prototypical images of the most ancient conceptualization of the world, i.e. primitive irrational awe and fear of hostile nature forces which are inaccessible to understanding, man learned to cognitively master the environment by distinguishing between different degrees of danger of phenomena.

This vector of danger awareness received inevitable orientation to the future, perceived in Christian theosophy as eternal bliss or torment. In the name of "happy" afterlife, man sought to follow Christian commandments and atone for sins in prayers and fasting, ensure his own security by magical rituals and minimizing social danger through speech aggression of varying degrees of intensity. Content specificity of protective communication genres is aimed at ensuring security of individual's personal, interpersonal and social space, verbalized in religious, magical and intolerant types of discourse.

\section{REFERENCES}

Allport G.W., 1954. The Nature of Prejudice. Reading, Addison-Wesley. $467 \mathrm{p}$.

Astafurova T.N., Olyanich A.V. 2015. Lingvosemiotika vlastnogo rituala [Lingua-Semiotics of Power Ritual]. Vestnik Volgogradskogo gosudarstvennogo universiteta. Seriya 2, Yazykoznaniye [Science Journal of Volgograd State University. Linguistics], no. 2 (26), pp. 4149. DOI: http://dx.doi.org/10.15688/ jvolsu2.2015.2.5.

Astafurova T.N., Olyanich A.V., 2018. Semiolinguistics of Sacred Power. Vestnik Volgogradskogo gosudarstvennogo universiteta. Seriya 2, Yazykoznaniye [Science Journal of Volgograd State University. Linguistics], vol. 17, no. 4, pp. 180-187. DOI: https://doi.org/10.15688/jvolsu2.2018.4.17.

Bakhtin M.M., 1997. Problema rechevykh zhanrov [The Problem of Speech Genres]. Sobranie sochineniy. $V 7$ t. T. 5 [Collected Works. In 7 vols. Vol. 5]. Moscow, Russkie slovari Publ., pp. 159-206.

Benveniste E., 1971. General Linguistics. University of Miami Press. $371 \mathrm{p}$.

Condor S., 2006. Social Identity and Time. Robinson W.P., ed. Social Groups and Identities: Developing the Legacy of Henri Tajfel. London, Butterworth / Heinemann, pp. 285-315.

Dijk T.A. van, 1985. Prejudice in Discourse. Amsterdam, Benjamin. $170 \mathrm{p}$.

Ivanova O.F., 2002. Politkorrektnost v Rossii [Political Correctness in Russia]. Vestnik Evrazii [Acta Eurasica], no. 3. URL: https://elibrary.ru/ item.asp?id=9457411 (accessed 5 May 2018).

Luria A.R., 1998. Language and Consciousness. Moscow, Izd-vo Moskovskogo universiteta. $335 \mathrm{p}$.

Mechkovskaya N.I., 1998. Language and Religion. Moscow, Fair Publ. 352 p.

Morris C., 1938. Foundations of the Theory of Signs. New York, George Brazilles. 60 p.

Shcherbatykh Yu.V., 2007. Psychology of Fear. Moscow, Eksmo Publ. 512 p.

Shmelyova T.V., 1995. Rechevoy zhanr: opyt obshchefilologicheskogo osmysleniya [Speech Genre: the Experience of a General Philological Understanding]. Collegium, no. 1/2, pp. 57-65. 
Wetherell M., 1987. Unequal Egalitarianism: A Preliminary Study of Discourses Concerning Gender and Employment Opportunities. Social Psychology, vol. 26, iss. 1, pp. 59-71.
Wodak R., 1996. The Genesis of Racist Discourse in Austria since 1989. Caldas-Coulthard C.R., Coulthard M., eds. Texts and Practices: Readings in Critical Discourse Analysis. London, Routledge, pp. 107-128.

\section{Information about the Authors}

Tatyana N. Astafurova, Doctor of Sciences (Philology), Professor, Department of German and Romanic Philology, Volgograd State University, Prosp. Universitetsky, 100, 400062 Volgograd, Russia, pic@volsu.ru; Professor, Department of Linguistics and Intercultural Communication, Volgograd State Technical University, Prosp. Lenina, 28, 400005 Volgograd, Russia, mkk_2012@vgasu.ru, https://orcid.org/0000-0002-1299-8109

Andrey V. Olyanich, Doctor of Sciences (Philology), Professor, Department of English Philology, Adyghe State University, Pervomayskaya St., 208, 385000 Maykop, Russia, aolyanich@mail.ru, https://orcid.org/0000-0003-3990-5707

\section{Информация об авторах}

Татьяна Николаевна Астафурова, доктор филологических наук, профессор кафедры германской и романской филологии, Волгоградский государственный университет, просп. Университетский, 100, 400062 г. Волгоград, Россия, pic@volsu.ru; профессор кафедры лингвистики и межкультурной коммуникации, Волгоградский государственный технический университет, просп. Ленина, 28, 400005 г. Волгоград, Россия, mkk_2012@vgasu.ru, https://orcid.org/0000-0002-1299-8109

Андрей Владимирович Олянич, доктор филологических наук, профессор кафедры английской филологии, Адыгейский государственный университет, ул. Первомайская, 208, 385000 г. Майкоп, Россия, aolyanich@mail.ru, https://orcid.org/0000-0003-3990-5707 